\title{
First record of Cnidocodon leopoldi Bouillon, 1978 (Cnidaria: Anthoathecata) in the Atlantic Ocean
}

\author{
Everton Giachini Tosetto ${ }^{1,5}$; Arnaud Bertrand ${ }^{1,2,3,6}$; Sigrid Neumann-Leitão ${ }^{1,7}$ \& Miodeli Nogueira-Jr. ${ }^{4,8}$ \\ ${ }^{1}$ Universidade Federal de Pernambuco (UFPE), Centro de Tecnologia e Geociências (CTG), Departamento de Oceanografia. Recife, PE, Brasil. \\ 2 Institut de Recherche pour le Développement (IRD), MARBEC, Univ Montpellier, CNRS, Ifremer, IRD, Sète, France. \\ ${ }^{3}$ Universidade Federal Rural de Pernambuco (UFRPE), Departamento de Pesca e Aquicultura (DEPAQ). Recife, PE, Brasil. \\ ${ }^{4}$ Universidade Federal da Paraíba (UFPB), Centro de Ciências Exatas e da Natureza (CCEN), Departamento de Sistemática e Ecologia (DSE). \\ João Pessoa, PB, Brasil. \\ ${ }^{5}$ ORCID: http://orcid.org/0000-0002-4020-0942. E-mail: evertontosetto@hotmail.com (corresponding author) \\ ${ }^{6}$ ORCID: http://orcid.org/0000-0003-4723-179X. E-mail: arnaud.bertrand@ird.fr \\ 7 ORCID: http://orcid.org/0000-0001-7878-8772. E-mail: sigridnl@uol.com.br \\ ${ }^{8}$ ORCID: http://orcid.org/0000-0001-5409-8312. E-mail: miodeli@gmail.com
}

\begin{abstract}
Specimens of the hydromedusa Cnidocodon leopoldi Bouillon, 1978 were collected in waters off the northeast Brazilian coast between $7.4^{\circ} \mathrm{S}, 34.3^{\circ} \mathrm{W}$ and $8.7^{\circ} \mathrm{S}, 34.8^{\circ} \mathrm{W}$. The genus can be distinguished from other anthomedusae by the presence of four marginal perradial bulbs having an adaxial nematocyst cushion and branched capitate tentacles, an umbrella with scattered nematocysts, and gonads around a cylindrical manubrium shorter than the umbrella. Specimens were assigned to C. leopoldi due the tentacles with 4-5 branches and the absence of ocelli on tentacle bulbs differing from the congeneric Cnidocodon ocellata Huang, Xu, Lin \& Qiu, 2008. This study represents the first record of the species in the Atlantic Ocean.
\end{abstract}

Keywords. Jellyfish; Cnidaria; Hydromedusae; Anthomedusae; Taxonomy.

\section{INTRODUCTION}

Medusae from the genus Cnidocodon Bouillon, 1978 are distinguished by the presence of four perradial bulbs having an adaxial nematocyst pad and a tentacle ending in a cluster of capitate branches, an umbrella with scattered statocysts, and gonads around a cylindrical manubrium which is shorter than the umbrella (Bouillon, 1978; Bouillon et al., 2006).

Although its medusae are easily recognizable, the phylogenetic position of the genus is still uncertain. When first described, it was placed in the family Corymorphidae Allman, 1872 and later in the Euphysidae Haeckel, 1879 (Bouillon, 1978; Bouillon et al., 2006). Both taxa have gone through several rearrangements and are currently considered synonyms (Petersen, 1990; Schuchert, 2021). Therefore, in the current classification, the family Corymorphidae encompasses genera from the suborder Aplanulata whose medusae have cylindrical manubrium with circular base and simple mouth and 1-4 marginal tentacles either with equal or different structure (Collins et al., 2005; Bouillon et al., 2006). Although Cnidocodon matches with this diagnosis, the absence of a robust set of characters for the medusae stage transformed the family in an all-embracing taxa and since the polyp stage of Cnidocodon is still unknown it is currently included among Aplanulata as incertae sedis (Schuchert, 2021).

Cnidocodon is a rare genus with few records since its original description. The knowledge of its geographical distribution is therefore important for better understanding of biogeographical patterns and ecological processes associated with the species, and also for further collection of specimens for molecular analysis to elucidate the phylogenetic questions raised above. In the present work, we recorded for the first time the species Cnidocodon leopoldi Bouillon, 1978 in the Atlantic Ocean and the genus Cnidocodon in the South Atlantic. We also provide a comprehensive overview of the global distribution of Cnidocodon species.

\section{MATERIAL AND METHODS}

Five specimens were collected in two stations (Table 1) during the "Acoustics along the Brazilian coast" survey (ABRACOS 2), carried out on April 2017, on board of the French R/V ANTEA off Northeast Brazil (Bertrand, 2017). Samples were collected through oblique hauls, using a bongo 
Table 1. Cnidocodon leopoldi occurrences off northeast Brazil. SST = Sea surface temperature, SSS = Sea surface salinity.

\begin{tabular}{lcccccc}
\hline Location & Date & $\begin{array}{c}\text { Number of } \\
\text { specimens }\end{array}$ & $\begin{array}{c}\text { Abundance } \\
\text { (ind.100 } \mathbf{~ m}^{-3} \text { ) }\end{array}$ & $\begin{array}{c}\text { SST } \\
\left({ }^{\circ} \mathrm{C}\right)\end{array}$ & sSS & $\begin{array}{c}\text { Bottom } \\
\text { depth }(\mathbf{m})\end{array}$ \\
\hline $7.4^{\circ} \mathrm{S}, 34.3^{\circ} \mathrm{W}$ & $2017 / 04 / 13$ & 4 & 5.6 & 28.8 & 37.3 & 49 \\
$8.7^{\circ} \mathrm{S}, 34.8^{\circ} \mathrm{W}$ & $2017 / 04 / 15$ & 1 & 0.46 & 28.9 & 36.9 & 3170 \\
\hline
\end{tabular}

plankton net with $300 \mu \mathrm{m}$ mesh size and $0.6 \mathrm{~m}$ mouth opening, from near bottom to surface over the continental shelf, and $200 \mathrm{~m}$ depth to surface in open waters. Surface temperature and salinity was observed using a Seabird 911 CTD profiler. Material collected was preserved with $4 \%$ formaldehyde solution buffered with sodium tetraborate $\left(0.5 \mathrm{~g}^{-1} \mathrm{I}^{-1}\right.$. Specimens were deposited in the Museu de Invertebrados Paulo Young from Universidade Federal da Paraíba (CIPY1126 and CIPY1127). All procedures performed in this research were in accordance with the ethical standards of the Universidade Federal de Pernambuco. The authors obtained all necessary permits for sampling and observational field studies from the competent authority (SISBIO license number 47270-5).

\section{RESULTS}

The five specimens (Table 1) present an almost globular umbrella without apical projection, ranging from 0.8 to $1.5 \mathrm{~mm}$ high and wide, with scattered nematocysts over the exumbrella. The mesoglea is thick and with opaque appearance in formalin fixed material (Fig. 1a). The manubria are cylindrical, occupying more than $3 / 4$ of bell cavity with circular mouth and without gastric peduncle (Fig. 1a). The gonads completely encircle the manubrium with exception of the region of the mouth (Fig. 1a). There are four perradial tentacle bulbs without ocelli, each with an adaxial nematocyst cushion (arrow in Fig. 1b). From each bulb, a short (approximately $0.1 \mathrm{~mm}$ ) tentacle stem arises and divides in 4-5 capitate branches of more or less equal lengths (Fig. 1b).

\section{DICUSSION}

The unique combination of four tentacle bulbs with adaxial cnidocyst cushion and short tentacles with capitate branches, gonads encircling the cylindrical manubrium, and scattered nematocysts over the exumbrella, observed in the present specimens matches the diagnosis of Cnidocodon (Bouillon, 1978; Bouillon et al., 2006). The genus was first described based on C. leopoldi. Cnidocodon xiamensis (Zhang \& Wu, 1981) was later described (as Ramus xiamenensis Zhang \& Wu, 1981) without scattered nematocysts and with more branches on tentacles (5-8) but its validity has been questioned and currently is considered a junior synonym of $C$. leopoldi (Huang et al., 2008; Schuchert, 2021). Other species, Cnidocodon ocellata Huang, Xu, Lin \& Qiu, 2008 has 6-9 capitate branches of different sizes and an abaxial ocellus on each bulb (Huang et al., 2008). Since the present specimens do not have any ocelli and have only 4-5 branches on each tentacle, its traits match with the diagnosis of C. leopoldi.

Although the general morphology of the present specimens is remarkably close to C. leopoldi, small discrepancies must be highlighted. In the original description the umbrella was higher than wide, with manubrium occupying half of the bell cavity, different from our specimens with the umbrella as high as wide, and relatively longer manubrium. These discrepancies may be due to intraspecific variability, age difference, and/or distortion after formalin fixation. In fact, Bouillon (1978) reported that bulbs usually flexed towards the inside of the umbrella under the action of preservative liquids. Another hypothesis would be that both materials might represent distinct cryptic species, as may be suggested by its quite disjoint distribution (Fig. 2) and the likely short lifespan. Detailed analyses including other life cycle stages as well as molecular data should be conducted in both localities to check this possibility. In addition, Cnidocodon sp. was reported in the Caribbean Sea off Belize (Larson, 1982). Unfortunately, neither morphological remarks nor the reason to not give a specific name (e.g., destroyed, young, not matching previous descriptions) were provided (Larson, 1982), not allowing morphological comparisons.

Cnidocodon leopoldi (and the genus Cnidocodon) was described from specimens collected in the Bismarck Sea off Papua New Guinea (Western Pacific; Bouillon, 1978; Fig. 2). In the western Pacific Ocean, the species was reported off Southeast Asia, where the congeneric C. ocellata was reported as well. In the Indian Ocean, C. leopoldi was reported several times off the coast of India, around oceanic islands in the Arabian Sea and Bay of Bengal, and off East South Africa in the area under influence of the Agulhas Current (Fig. 2).

In the present study, we report the occurrence of $C$. leopoldi in the Atlantic Ocean for the first time, indicating the species is ubiquitous to tropical areas from the three ocean basins (Fig. 2). The specimens were obtained from epipelagic plankton samples over the continental shelf and slope collected off Northeast Brazil in the western border of the ocean. Current and previous reports of both species of the genus were always located in waters not far from the coast or islands. An expected result since Anthoathecata hydrozoans often require substrates over the continental shelf for hydroid settlement (Bouillon et al., 2006).

Cnidocodon leopoldi was only observed in two of the 47 stations sampled during the ABRACOS 2 survey (Bertrand, 2017): one station over the Pernambuco Plateau, where higher density was observed $(n=4)$; and another station in its vicinity $(n=1)$ (see Table 1$)$. In this particular area, the strong western boundary currents that flow coastward South America, which transports warm and salty water and its associated planktonic fauna over the continental shelf, have its influence reduced due to interactions with bottom topography. Thus, oceanward transport of coastal water is observed in this area (Dossa et al., 2021; Tosetto et al., 2021a). This hydrographic configuration has significant implications in the structure of cnidarian community and possibly the entire ecosystem (Tosetto et al., 2021a). 

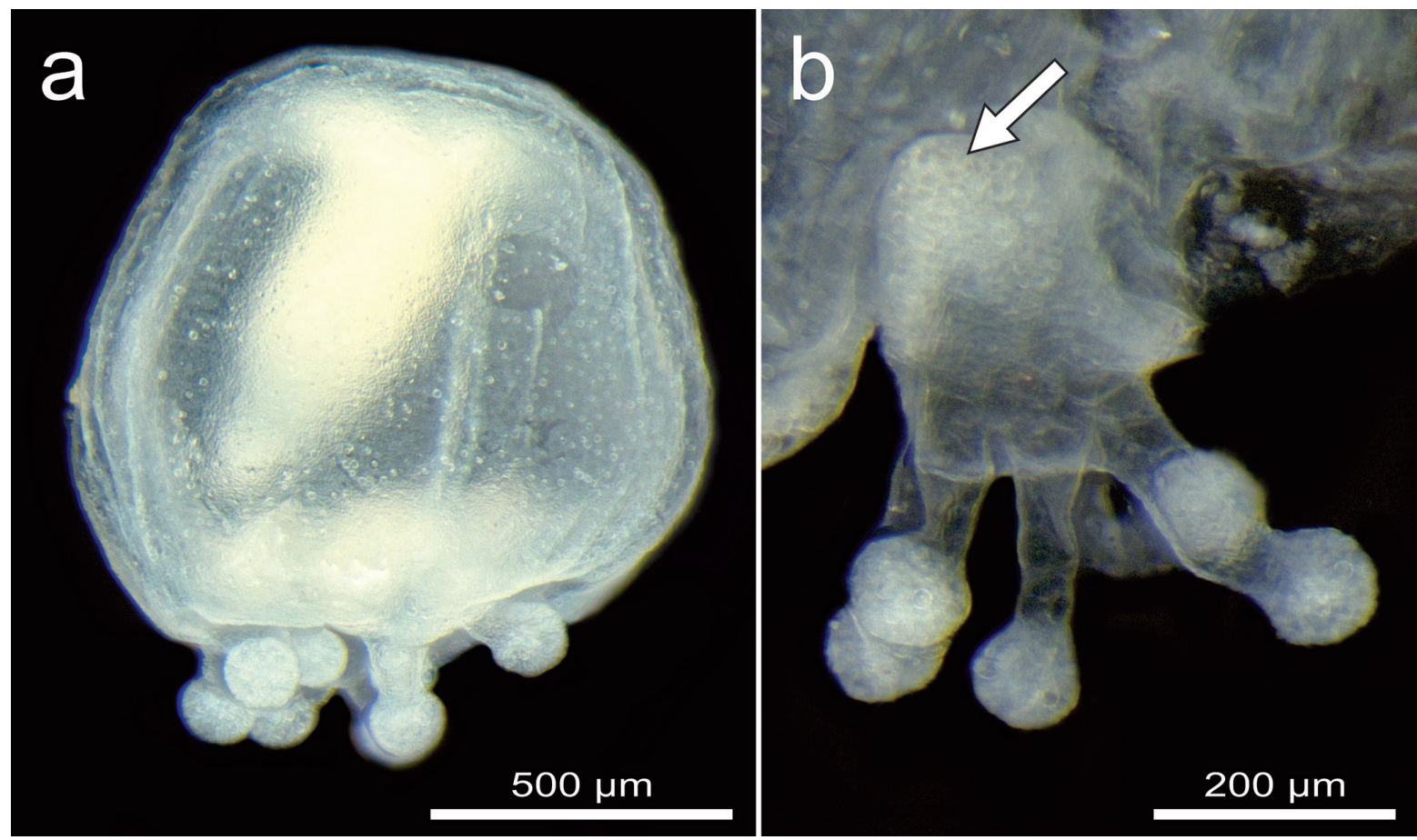

Figure 1. Cnidocodon leopoldi from Western Atlantic Ocean. (A) Lateral view. (B) Detail on marginal bulb with branched capitate tentacles and adaxial nematocyst pad (arrow).

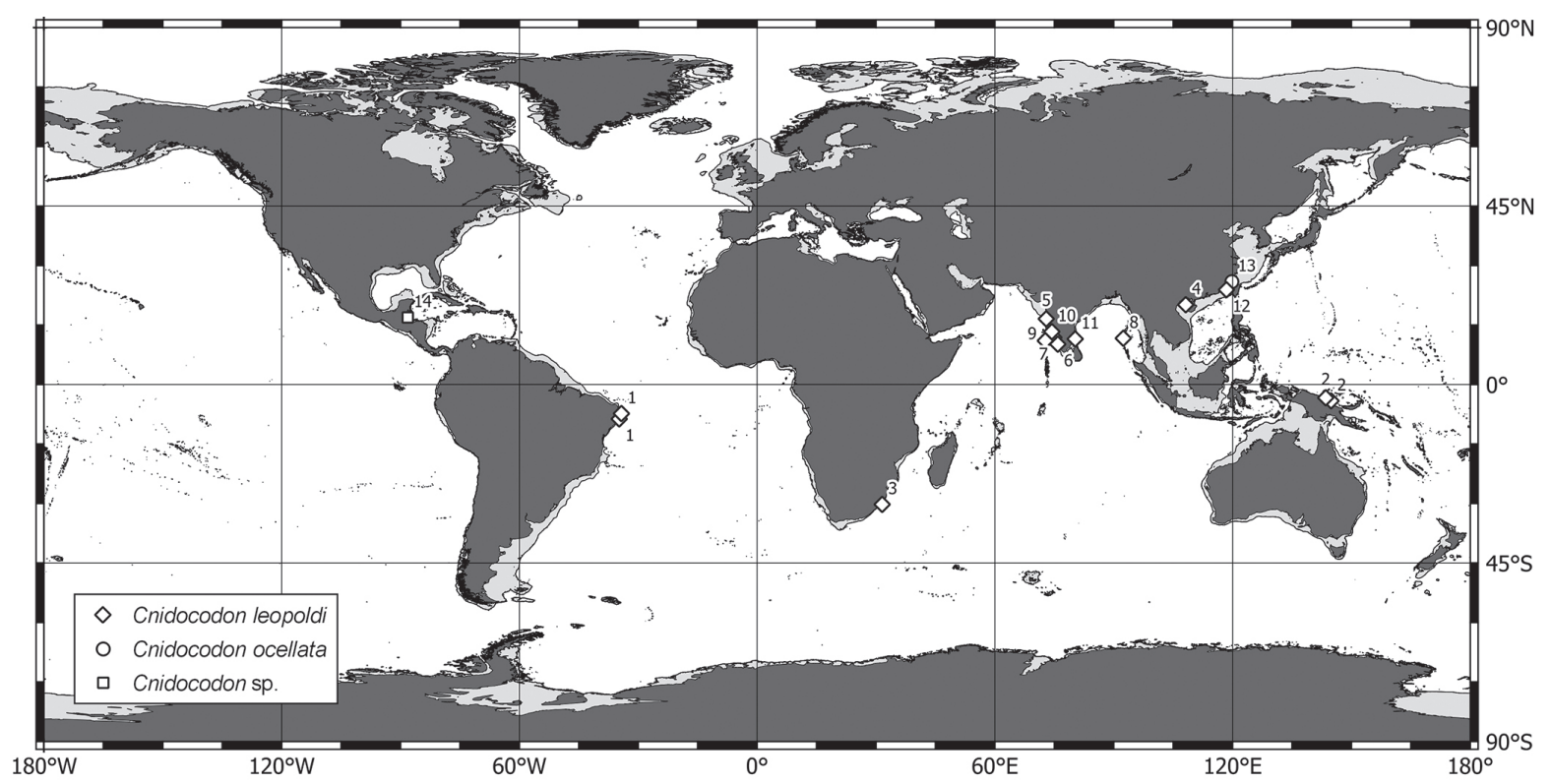

Figure 2. Global distribution of Cnidocodon species based on this study and literature records. $1=$ this study, $2=$ (Bouillon, 1978), $3=$ (Buecher et al., 2005), $4=$ (Du et al., 2012), $5=$ (Nagale et al., 2012), $6=$ (Santhakumari \& Nair, 1999), $7=($ Santhakumari, 1986), $8=($ Santhakumari, 1993), $9=($ Santhakumari, 1996), $10=$ (Santhakumari, 1997a), $11=($ Santhakumari, 1997b), $12=$ (Zhang \& Wu, 1981), $13=$ (Huang et al., 2008) and $14=$ (Larson, 1982). Shaded area and line indicate the $250 \mathrm{~m}$ isobath, roughly corresponding to the shelf break.

Historically, planktonic cnidarian biodiversity from tropical areas in the western border of the Atlantic Ocean were understudied comparing to subtropical and temperate provinces. With recent progress in oceanographic research in Northeast Brazil this situation started changing not only for cnidarians (e.g., Farias et al., 2020; Tosetto et al., 2018, 2020, 2021a, 2021 b) but also for other marine animals (e.g., Eduardo et al., 2018, 2020; Alves-Jr. et al., 2019. Thus, the current report contributes not only to the understanding of local biodiversity, but also for an adequate comprehension of regional and global biogeographic and diversity patterns. In conclusion, we extend- ed the known geographical distribution of C. leopoldi to the Western Tropical Atlantic Ocean and confirm the presence of the genus in this ocean basin. Based on the distribution records we also conclude C. leopoldi is a typical shallow water species with all records located near the coast or ocean islands.

\section{ACKNOWLEDGMENTS}

We acknowledge the French oceanographic fleet for funding the survey ABRAÇOS 2 and the officers, crew 
and scientific team of the R/V Antea for their contribution to the success of the operations. The present study could not have been done without the support of all participants from the LABZOO and the laboratories at Universidade Federal de Pernambuco and Universidade Federal Rural de Pernambuco. We thank the CNPq (Conselho Nacional de Desenvolvimento Científico e Tecnológico), which provided student scholarship to EGT (grant 140897/2017-8). This work is a contribution to the LMI TAPIOCA (https://tapioca.ird.fr) and CAPES/COFECUB program (88881.142689/2017-01).

\section{AUTHORS' CONTRIBUTIONS}

E.G.T: Conceptualization; data curation; formal analysis; investigation; methodology; writing - original draft; writing - review \& editing. S.N.L.: Conceptualization; funding acquisition; project administration; resources; writing - review \& editing. A.B.: Conceptualization; funding acquisition; project administration; resources; writing - review \& editing. M.N.J.: Conceptualization; data curation; formal analysis; investigation; methodology; resources; writing - review \& editing.

\section{CONFLICT OF INTEREST}

The authors declare that they have no conflict of interest.

\section{REFERENCES}

Alves-Jr., F.D.A.; Silva, E.D.S.; De Araújo, M.D.S.L.C.; Cardoso, I.; Bertrand, A. \& Souza-Filho, J.F. 2019. Taxonomy of deep-sea shrimps of the Superfamily Oplophoroidea Dana 1852 (Decapoda: Caridea) from Southwestern Atlantic. Zootaxa, 4613: 401-442. D0I

Bertrand, A. 2017. ABRACOS 2 cruise, Antea R/V. Available: http://doi. org/10.17600/17004100. Access: 20/07/2021.

Bouillon, J. 1978. Hydroméduses de la Mer de Bismarck (Papouasie NouvelleGuinée. Partie I: Anthomedusae Capitata (Hydrozoa-Cnidaria). Cahiers de Biologie Marine, 19: 249-297.

Bouillon, J.; Gravili, C.; Pagès, F.; Gili, J.M. \& Boero, F. (Eds.). 2006. An introduction to Hydrozoa. Mémoires du Muséum National d'Histoire Naturelle, 194: 1-591.

Buecher, E.; Goy, J. \& Gibbons, M.J. 2005. Hydromedusae of the Agulhas Current. African Invertebrates, 46: 27-69.

Collins, A.G.; Winkelmann, S.; Hadrys, H. \& Schierwater, B. 2005. Phylogeny of Capitata and Corynidae (Cnidaria, Hydrozoa) in light of mitochondrial 16S rDNA data. Zoologica Scripta, 34: 91-99. D0I

Dossa, A.N.; Silva, A.C.; Chaigneau, A.; Eldin, G.; Araujo, M. \& Bertrand, A. 2021. Near-surface western boundary circulation off Northeast Brazil. Progress in Oceanography, 190 (102475). D01

Du, F.; Xu, Z.; Huang, J. \& Guo, D. 2012. Studies on the medusae (cnidaria) from the Beibu Gulf in the northern South China Sea, with description of three new species. Acta Zootaxonomica Sinica, 37: 506-519.

Eduardo, L.N.; Bertrand, A.; Mincarone, M.M.; Santos, L.V.; Frédou, T.; Assunção, R.V.; Silva, A.; Ménard, F.; Schwamborn, R.; Le Loc'h, F. \& Lucena-Frédou, F. 2020. Hatchetfishes (Stomiiformes: Sternoptychidae) biodiversity, trophic ecology, vertical niche partitioning and functional roles in the western Tropical Atlantic. Progress in Oceanography, 187(102389). D0I

Eduardo, L.N.; Frédou, T.; Lira, A.S.; Ferreira, B.P.; Bertrand, A.; Ménard, F. \& Frédou, F.L. 2018. Identifying key habitat and spatial patterns of fish biodiversity in the tropical Brazilian continental shelf. Continental Shelf Research, 166: 108-118. DOI

Farias, G.B.; Leitão, S.N.; Melo, P.A.M. de C.; Nogueira-Jr., M. \& Tosetto, E.G. 2020. First in situ record of the medusa stage of Cladonema radiatum (Cnidaria: Anthoathecata) in the South Atlantic Ocean. Ocean and Coastal Research, 68: e20349. DOI

Huang, J.; Xu, Z.; Lin, J. \& Qiu, M. 2008. Three new species of Anthomedusae (Hydrozoa, Hydroidomedusae) from the Fujian Sea Water. Journal of Xiamen University (Natural Science), 47: 408-412.

Larson, R.J. 1982. Medusae (Cnidaria) from Carrie Bow Cay, Belize. The Atlantic Barrier Reef at Carrie Bow Cay, Belize, I Structure and communities. Smithsonian Contributions to the Marine Sciences, 12: 253-258.

Nagale, P.; Bhave, V. \& Apte, D. 2012. A review of Hydrozoa from Maharashtra. Biodiversity and Conservation of Coastal and Marine Ecosystems of India, 1: 84-88.

Petersen, K.W. 1990. Evolution and taxonomy in capitate hydroids and medusae (Cnidaria: Hydrozoa). Zoological Journal of the Linnean Society, 100: 101-231. DOI

Santhakumari, V. 1986. A new record of Cnidocodon leopoldi Bouillon (Anthomedusae, Hydrozoa) from Indian Ocean with a note on its variation. Bulletin of the Department of Marine Science University Cochin, 14: $33-37$

Santhakumari, V. 1993. A study of medusae from Andaman and Nicobar waters. Journal of the Zoological Society of Kerala, 3: 37-43.

Santhakumari, V. 1996. The Medusae from the Sea around Laccadive Group of Islands (7-18 $\left.{ }^{\circ} / 69-76^{\circ} \mathrm{E}\right)$. In: Pillai, V.K.; Abidi, S.A.H.; Ravindran, V.; Balachandran, K.K.\&Agadi, V.V. (Eds.). Proceedings of the Second Workshop on Scientific Results of FORV Sagar Sampada, Workshop on Scientific Results of FORV Sagar Samapada. New Delhi, Dept. of Ocean Development,.

Santhakumari, V. 1997a. Species composition, distribution and abundance of Hydromedusae in the Exclusive Economic Zone of the East Coast of India. Publications of the Seto Marine Biological Laboratory, 38: 53-61.

Santhakumari, V. 1997b. Hydromedusae from the Exclusive Economic Zone of West Coast. Recent Advances in Ecobiological Research, 1: 185-195.

Santhakumari, V. \& Nair, V.R. 1999. Distribution of hydromedusae from the exclusive economic zone of the west and east coasts of India. Indian Journal of Marine Sciences, 28: 150-157.

Schuchert, P. 2021. World Hydrozoa Database. http://www.marinespecies. org. Access: 05/05/2018.

Tosetto, E.G.; Neumann-Leitão, S. \& Nogueira-Jr., M. 2018. New records of Pegantha spp. (Hydrozoa: Narcomedusae) off Northern Brazil. Papéis Avulsos de Zoologia, 58: e20185849. DOI

Tosetto, E.G.; Neumann-Leitão, S. \& Nogueira-Jr., M. 2020. New species of Eirenidae (Hydrozoa: Leptothecata) from the Amazonian coast (northern Brazil). Scientia Marina, 84: 421-430. DOI

Tosetto, E.G.; Bertrand, A.; Neumann-Leitão, S.; Costa da Silva, A. \& Nogueira-Jr., M. 2021a. Spatial patterns in planktonic cnidarian distribution in the western boundary current system of the tropical South Atlantic Ocean. Journal of Plankton Research, 43: 270-287. DOI

Tosetto, E.G.; Neumann-Leitão, S.; Bertrand, A. \& Nogueira-Jr., M. 2021b. First record of Cirrholovenia polynema (Hydrozoa: Leptothecata) in the Western Atlantic Ocean. Ocean and Coastal Research, 69: e21006. D0I

Zhang, J. \& Wu, Y. 1981. On a new genus and species of the hydromedusae from Xiamen Harbour, Fujin Provice, China. Acta Oceanologica Sinica, 3: 184-187. 